\title{
Preventieve politiecontroles en interne grenscontroles in het Schengengebied
}

\author{
Peter Rodrigues \& Maartje van der Woude
}

\section{Inleiding}

De afgelopen jaren zijn een grote uitdaging gebleken voor de Europese Unie (EU) en in het bijzonder voor de lidstaten die het verdrag van Schengen hebben ondertekend. ${ }^{1}$ De EU zat vijf jaar geleden als gevolg van de in 2010 in diverse landen ontsproten Arabische lente nog redelijk aan het begin van wat - zo bleek later een moeizaam hoofdstuk in haar geschiedenis zou worden. De aanhoudende komst van migranten vanuit met name Syrië, Afghanistan en Irak naar het Europese continent zette een van de fundamenten van de EU, en in het bijzonder Schengen, onder druk: het vrije verkeer van personen en de daarbij behorende open Europese binnengrenzen. Daarnaast geconfronteerd met aanzienlijke aantallen dikwijls door geweld gedwongen ontheemden uit de hoorn van Afrika die via diverse routes het Europese vasteland bereikten, werd in 2015 duidelijk dat de buitengrenzen van Schengen in de praktijk niet de werende functie boden die de lidstaten bij het in werking treden van het Schengenverdrag voor ogen hadden. In diverse lidstaten maakt men zich zorgen over de mogelijke bedreiging die de vluchtelingen vormen voor de sociale veiligheid en nationale identiteit. In publieke en politieke discussies wordt het thema 'migratie' dan ook dikwijls in een adem genoemd met criminaliteit en (on)veiligheid. De koppeling tussen migratie en veiligheid gaat verder dan 'reguliere' criminaliteit. Na de aanslagen in Parijs in november 2015 verschenen er verontrustende berichten in de media over hoe terreurorganisatie ISIS van de chaos aan de Europese buitengrenzen gebruik zou maken om terreurcellen voet aan Europese bodem te doen krijgen om aanslagen voor te bereiden en te plegen. ${ }^{2}$ Waar er al zorgen bestonden over de vermeende link tussen migratie en terrorisme, hebben voornoemde aanslagen een katalyserend effect gehad dat voorts alleen maar verder leek te worden bestendigd door andere aanslagen die in de jaren daarna zouden volgen.

In reactie op dit alles, en in het bijzonder op de realisatie dat de buitengrenzen niet de filterende functie leken te hebben waarop gedacht was te kunnen vertrouwen, zijn verschillende lidstaten actief de diverse mogelijkheden gaan benutten die de Schengengrenscode biedt om, ondanks de open binnengrenzen, toch toezicht te kunnen houden op intra-Schengengrensmobiliteit. Waar diverse landen ervoor hebben gekozen om de meest ingrijpende optie in te zetten, te weten het

1 Regulation (EU) 2016/399 of the European Parliament and of the Council of 9 March 2016 on a Union Code on the rules governing the movement of persons across borders (Schengen Borders Code).

2 Zie bijvoorbeeld: http://www.independent.co.uk/news/world/europe/isis-fighters-virtuallyimpossible-to-detect-as-group-continues-to-use-fake-passports-to-exploit-a6836376.html. 
tijdelijk weer herintroduceren van grenscontroles, investeren andere landen in preventieve politiecontroles of in immigratiecontroles die worden uitgevoerd in een gebied rondom de intra-Schengengrenzen. Dit laatste wordt, zoals hieronder verder besproken zal worden, ook expliciet aanbevolen door de Europese Commissie (EC). Deze preventieve controles gaan doorgaans gepaard met aanzienlijke discretionaire beslisruimte voor de ambtenaren belast met de uitvoering daarvan. Deze discretionaire ruimte is, hoewel deels noodzakelijk, niet onproblematisch met het oog op praktijken als etnisch profileren en détournement de pouvoir. ${ }^{3}$

In deze bijdrage willen we reflecteren op de afweging die lidstaten (moeten) maken op de mobiliteit van personen in tijden van migratie en grensoverschrijdende criminaliteit. Waar het Schengen-acquis twee mogelijkheden geeft, ofwel het uitvoeren van politie- of immigratiecontroles in grensgebieden ofwel de meer ingrijpende optie om daadwerkelijke grenscontroles tijdelijk weer in te voeren, is het aan de lidstaten om te bepalen welke van deze twee reacties wenselijk en noodzakelijk wordt geacht. Zoals we in het navolgende zullen betogen, is het de vraag in hoeverre een dergelijke gang van zaken, die ook nog verder lijkt te worden gecompliceerd door recente aanbevelingen vanuit de EC over hoe om te gaan met de intra-Schengengrenzen, een eenduidig en geharmoniseerd beleid doorkruist. We zullen in onze bijdrage onder meer putten uit Nederlandse cases, aangezien Nederland een van de weinige landen is die reeds sinds het ondertekenen van het Schengen-acquis openlijk gebruikmaakt van de mogelijkheid om immigratiecontroles uit te voeren in intra-Schengengrensgebieden. Dit gebeurt in de vorm van het Mobiel Toezicht Veiligheid (MTV) zoals uitgevoerd door de Koninklijke Marechaussee (KMar). ${ }^{4}$ Het MTV is sinds de inwerkingtreding in 1994 aan diverse veranderingen onderhevig geweest, maar lijkt nu een voorbeeld voor verschillende andere Europese landen die zich genoodzaakt voelen om de Europese binnengrenzen enigszins te monitoren maar die niet (meer) hun toevlucht willen, of kunnen, zoeken in de drastische maatregel om weer grenscontroles in te voeren.

\section{Preventieve politiecontroles}

Op 12 mei 2017 heeft de EC een aanbeveling gedaan inzake evenredige politiecontroles en politiële samenwerking in het Schengengebied. ${ }^{5}$ De aanbeveling is een vervolg op richtsnoeren inzake politiële maatregelen in de binnengrenszones die de EC in 2012 heeft uitgevaardigd. ${ }^{6}$ Deze richtsnoeren zijn op basis van de opgedane ervaring van de afgelopen jaren herzien. Daarbij worden relevante

3 M.A.H. van der Woude \& J. Brouwer, 'Searching for "Illegal" Junk in the Trunk: Underlying Intentions of (Cr)Immigration Controls in Schengen's Internal Border Areas', New Criminal Law Review 2017, 20(1): 157-179.

4 Zie voor een uitvoerige beschrijving van de Nederlandse praktijk M.A.H. van der Woude, J. Brouwer \& T.J.M. Dekkers, Beslissen in grensgebieden: een onderzoek naar het Mobiel Toezicht Veiligheid zoals uitgevoerd door de Koninklijke Marechaussee, Den Haag: Boom criminologie 2016.

5 Aanbeveling (EU) 2017/820.

$6 \operatorname{COM}(2012) 230$. 
rechtspraak over de politiecontroles meegenomen en nieuwe mogelijkheden die voortvloeien uit technologische ontwikkelingen. In een ruimte zonder binnengrenstoezicht dient er een gemeenschappelijke systematiek te zijn voor het geval dat er zich een grensoverschrijdende bedreiging voordoet van de openbare orde of de binnenlandse veiligheid. De hiervoor in paragraaf 1 beschreven ontwikkelingen in de EU maken duidelijk dat maatregelen inderdaad noodzakelijk zijn voor het waarborgen van de veiligheid. Minder eenduidig is welke maatregelen adequaat en Unierechtelijk toegestaan zijn, waarbij ook de uitgeoefende bevoegdheden in overeenstemming moeten zijn met het Unierecht. De Schengengrenscode bepaalt dat de afwezigheid van grenstoezicht aan de binnengrenzen geen afbreuk mag doen aan de uitoefening van de politiebevoegdheid door de bevoegde nationale instanties van de lidstaten, voor zover de uitoefening van de politiebevoegdheid niet hetzelfde effect heeft als grenscontroles. ${ }^{7}$ In het Adil-arrest concretiseert het EU Hof van Justitie deze regel en stelt hij dat de maatregelen geen grenstoezicht tot doel mogen hebben (1) en gebaseerd dienen te zijn op algemene politie-informatie en -ervaring met betrekking tot mogelijke bedreigingen van de openbare veiligheid (2). ${ }^{8}$ Tevens dienen deze maatregelen met name bedoeld te zijn ter bestrijding van grensoverschrijdende criminaliteit (3) en te worden gepland en uitgevoerd op een manier die duidelijk verschilt van de systematische controles van personen aan de buitengrenzen en op basis van controles ter plaatse worden uitgevoerd (4). In het Adil-arrest staat de Nederlandse regelgeving voor het MTV centraal. Nadat de Afdeling bestuursrechtspraak deze regelgeving eerder in strijd met het Unierecht heeft geoordeeld, ${ }^{9}$ stelt zij vervolgens de prejudiciële vraag hoe artikel 23 Schengengrenscode op dit punt moet worden uitgelegd. ${ }^{10}$ Daarop formuleert het EU Hof van Justitie in het Adil-arrest de hiervoor genoemde vier criteria waaronder controle na grensoverschrijding is toegestaan. Volgens de EC rechtvaardigen de huidige omstandigheden, 'waarin sprake is van bedreigingen van de openbare orde of de binnenlandse veiligheid in verband met terrorisme en andere zware grensoverschrijdende criminaliteit alsook van risico's van secundaire bewegingen van personen die de buitengrenzen op irreguliere wijze hebben overschreden', politiecontroles op het gehele grondgebied van de lidstaten te intensiveren. Dat geldt ook voor de grensgebieden en de belangrijkste vervoersverbindingen, mits de maatregel evenredig is aan de geconstateerde bedreigingen. In Nederland is het MTV-beleid de afgelopen jaren aangescherpt. ${ }^{11}$

De nadruk op grensgebieden is ingegeven doordat zich daar specifieke risico's inzake grensoverschrijdende criminaliteit voordoen, zoals niet-toegestane secun-

7 Artikel 23 Verordening (EU) 2016/399.

8 EUHvJ 19 juli 2012, C-278/12 (PPU) (Adil), ECLI:EU:C:2012:508.

9 ABRS 4 juni 2012, JV 2012/324, ECLI:NL:RVS:2012:BW7489.

10 ABRS 4 juni 2012, JV 2012/324, LJN: BW7489. Wij houden het huidige (ongewijzigde) artikel 23 aan dat sinds 9 maart 2016 van toepassing is. Voordien betrof het artikel 21. De strijdigheid was mede gebaseerd op EUHvJ 22 juni 2010, C-188/10 en C-189/10 (Melki en Abdeli), ECLI:EU:C: 2010:363.

11 Besluit van de Staatssecretaris van Veiligheid en Justitie van 2 maart 2016 tot tijdelijk afwijken van artikel 4.17a, derde, vierde en vijfde lid, van het Vreemdelingenbesluit 2000, Stcrt. 2016, nr. 12085 en zie ook Stcrt. 2017, nr. 55744. 
daire bewegingen van onderdanen van derde landen, migrantensmokkel en mensenhandel. De controle na grensoverschrijding heeft de voorkeur van de EC boven binnengrenscontroles. Deze controles zijn overigens geen Nederlandse aangelegenheid. Gedurende de laatste drie jaar heeft een aantal andere lidstaten ook de politiecontroles in de grensgebieden geïntensiveerd in verband met de toegenomen bedreigingen van de openbare orde of de binnenlandse veiligheid. Het betreft Oostenrijk, België, Tsjechië, Duitsland, Denemarken, Frankrijk, Italië, Slovenië en Zwitserland. Deze controles waren soms gericht op specifieke vervoersmiddelen, zoals treinen, of specifieke grensgebieden. In de eerdergenoemde Aanbeveling van mei 2017 moedigt de EC de lidstaten aan om beter gebruik te maken van hun politiële bevoegdheden en om voorrang te geven aan politiecontroles alvorens te besluiten tot de tijdelijke herinvoering van binnengrenstoezicht. De politiecontroles blijken vanwege hun flexibiliteit doeltreffender te zijn dan statisch binnengrenstoezicht. ${ }^{12}$ De maatregel mag echter geen onnodige belemmeringen voor het vrije verkeer van de burgers en goederen meebrengen, dient evenredig te zijn aan de bedreiging en mag geen schending van de grondrechten en met name het beginsel van non-discriminatie tot gevolg hebben. Wat ons betreft, zijn het evenredigheidsbeginsel en het discriminatieverbod belangrijke ijkpunten om de maatregelen te toetsen die lidstaten treffen.

Het blijft lastig te bepalen of controlemaatregelen vallen aan te merken als een verboden binnengrenscontrole of als een toegestane controle na binnengrensoverschrijding. Het Ambtsgericht Kehl stelde hierover prejudiciële vragen die het EU Hof van Justitie op 21 juni 2017 heeft beantwoord. ${ }^{13}$ Het gaat in deze zaak om twee vragen. ${ }^{14}$ Ten eerste of de Duitse federale politie bevoegd is ter afwending van gevaar politiecontroles uit te voeren tot dertig kilometer landinwaarts om illegale binnenkomst of strafbare feiten te voorkomen. Ten tweede of deze bevoegdheid aan boord van treinen en op terreinen of in gebouwen van de spoorwegen rechtmatig kan worden uitgeoefend. Wat was er gebeurd? Een derdelander is te voet de Europabrug van Straatsburg, Frankrijk, naar Kehl, Duitsland, overgestoken. De man wordt staande gehouden en zijn identiteit wordt gecontroleerd. Hierbij pleegt hij verzet. De zaak komt voor de rechter die constateert dat de Duitse politiemensen in de rechtmatige bediening van hun ambt waren, maar twijfelt gezien het Adil-arrest of het Duitse recht in overeenstemming is met het Unierecht en stelt daarover vragen aan het EU Hof van Justitie. Belangrijk is onder de aandacht te brengen dat de controlebevoegdheid van artikel 23 Schengengrenscode mag worden toegepast zonder dat er een verdenking tegen de persoon is en ook zonder dat er sprake is van bijzonder gedrag of dito omstandigheden.

Naar aanleiding van de eerste vraag gaat het Hof na of aan de vereisten van artikel 23 Schengengrenscode is voldaan en maakt daarbij een onderscheid tussen

14 Zie ook Maartje van der Woude op Leiden Law Blog, http://europeanbordercommunities.eu/blog/ a-bridge-over-schengens-troubled-borders. 
grenscontroles en controles na grensoverschrijding. Op grond van artikel 2 sub 10 zijn grenscontroles enkel bedoeld om na te gaan of betrokken personen het grondgebied van de lidstaten binnen mogen komen, dan wel mogen verlaten. ${ }^{15}$ De Duitse controles na grensoverschrijding hebben volgens het Hof daarentegen ook tot doel strafbare feiten te voorkomen. Daarbij moet met name aan migratiecriminaliteit gedacht worden, zoals illegale binnenkomst, mensenhandel en mensensmokkel. Het onderscheid dat hier door het Hof wordt gemaakt, overtuigt ons niet. Grenscontroles zijn natuurlijk ook bedoeld om migratiecriminaliteit te voorkomen. Het Hof loopt de criteria van het Adil-arrest na en merkt vervolgens op dat artikel 23 sub a Schengengrenscode geen uitputtende lijst van voorwaarden bevat waaraan politiecontroles moeten voldoen om niet te worden geacht hetzelfde effect te hebben als grenscontroles, noch een uitputtende lijst van doelstellingen die met deze maatregelen mogen worden nagestreefd. ${ }^{16}$ Het Adil-arrest betreft controles tot op twintig kilometer van de grens en in het onderhavige arrest is dat dertig kilometer. Dat acht het Hof geen bezwaar, maar stelt dat de verwijzende rechter moet nagaan of de maatregel voldoet aan de vereisten zoals eerder genoemd. Daarbij gaat het niet alleen om de regelgeving, waarbij het Hof twijfels uit of deze politiecontroles wel voldoen aan het vereiste dat deze niet hetzelfde effect mogen hebben als grenscontroles, maar ook om de feitelijke uitoefening. ${ }^{17}$ De nationale regeling dient volgens het Hof te voorzien in een kader dat voorkomt dat de controles het karakter van grenscontrole hebben. ${ }^{18}$

De tweede vraag betreft controles in treinen, spoorweggebouwen en terreinen van iedere persoon. Wij vragen ons af hoe zich dat verhoudt met het vereiste dat de controles niet systematisch mogen zijn en beperkt moeten zijn in frequentie, intensiteit en selectiviteit. Het Hof gaat hier niet op in en wijst erop dat naarmate de controles meer op grenscontroles lijken, de eisen van artikel 23 Schengengrenscode des te strikter moeten worden toegepast. ${ }^{19}$ In hoeverre de bevoegdheid daarmee in strijd komt, laat het Hof ter beantwoording aan de nationale rechter.

\section{Verbod interne grenscontrole in Schengen op de helling?}

Opmerkelijk is dat de EC een dag voordat zij haar aanbeveling over politiecontroles en politiële samenwerking in het Schengengebied publiceerde, de verlenging van binnengrenscontroles door Duitsland, Oostenrijk, Zweden, Noorwegen en Denemarken goedkeurde. ${ }^{20}$ Het betreft concrete grenscontroles:

- aan de landsgrens van Oostenrijk en Hongarije en Oostenrijk en Slovenië;

- aan de landsgrens tussen Duitsland en Oostenrijk; 
- aan de Deense havens met bootverbinding naar Duitsland en de DeensDuitse landgrens;

- $\quad$ in de Zweedse havens in de regio Zuid en West en de Öresundbrug;

- in de Noorse havens met bootverbinding naar Denemarken, Duitsland en Zweden.

Deze uitzonderingen op het verbod van binnengrenscontroles kunnen door de EC worden toegestaan op grond van artikel 29 Schengengrenscode. Sinds de invoering van deze mogelijkheid in 2016 is dit de derde verlenging van deze tijdelijke herinvoering van binnengrenscontroles. Deze maatregel lijkt haaks te staan op het idee dat politiecontroles na grensoverschrijding effectiever zijn dan grenscontroles. De herinvoering is het gevolg van de zogenoemde migratiecrisis van 2015 vanwege het intensieve gebruik van de westelijke Balkanroute door asielzoekers. Artikel 29 Schengengrenscode bepaalt dat in uitzonderlijke omstandigheden, waarbij als gevolg van aanhoudende ernstige gebreken met betrekking tot het buitengrenstoezicht, zoals bedoeld in artikel 23 Schengengrenscode, de algemene werking van de ruimte zonder binnengrenstoezicht in gevaar komt. Dat betreft dus het toezicht na grensoverschrijding zoals hiervoor besproken. Die omstandigheden dienen een ernstige bedreiging te vormen voor de openbare orde of de binnenlandse veiligheid binnen de ruimte zonder binnengrenstoezicht of binnen delen daarvan en kan het grenstoezicht aan de binnengrenzen opnieuw worden ingevoerd voor een periode van ten hoogste zes maanden. Die periode mag, indien de uitzonderlijke omstandigheden aanhouden, hooguit driemaal met een bijkomende periode van ten hoogste zes maanden worden verlengd. Een beperkte verlenging van interne grenscontrole op basis van artikel 29 Schengengrenscode is dus enkel gelegitimeerd indien ernstige gebreken in het buitengrenstoezicht consequenties hebben voor de openbare of de binnenlandse veiligheid in de desbetreffende lidstaat. Als legitimering voor de eerste verlenging in 2016 wijst de EC op het gebrekkige Griekse grensbewakingssysteem en bij de daarop volgende verlengingen op het grote aantal irreguliere migranten en asielzoekers op de Balkanroute. ${ }^{21}$ Uitgangspunt blijft dat de Unie haar burgers een ruimte biedt van vrijheid, veiligheid en recht zonder binnengrenzen (artikel 3 lid 2 Verdrag EU). Het Schengengebied is met 400 miljoen EU-burgers en haar bezoekers het grootste gebied ter wereld waar mensen vrij kunnen rondreizen. Maar de EC is zich ervan bewust dat migratiestromen zoals die zich in 2015 voordeden, met 1,2 miljoen mensen die toen bescherming in de EU zochten, ook problemen met betrekking tot de openbare orde en binnenlandse veiligheid kunnen veroorzaken. Vooral zijn de lidstaten die maatregelen hebben getroffen, bevreesd voor zogenoemde secundaire migratie vanuit Griekenland en Italië. Daarnaast neemt de vrees voor terroristische aanlagen in de EU toe, hetgeen nieuwe veiligheidsvraagstukken doet ontstaan. Hierbij lijkt zich een tegenstelling tussen noordwesten en zuidoosten voor te doen. Het zijn met name de lidstaten in het noordwesten van de EU die controlemaatregelen willen treffen om hun doorgaans sterkere verzorgingsstaat af te schermen van ongewenste en mogelijk onveilige 'freeriders'. Dit 
leidt tot verzet in de lidstaten in het zuidoosten die zich hierdoor geplaatst zien voor toenemende aantallen irreguliere migranten, die gezien het ontbreken van een stevig sociaal vangnet dikwijls onder erbarmelijke omstandigheden moeten leven. ${ }^{22}$ Migratie- en veiligheidsvraagstukken kennen naast juridische ook belangrijke geopolitieke componenten. Gezien het beperkte toepassingsbereik van artikel 29 Schengengrenscode is de vraag of een derde (!) verlenging van de interne grenscontroles niet te lichtvaardig is verleend en of andere middelen, zoals controle na grensoverschrijding, geen oplossing boden. ${ }^{23}$

Inmiddels heeft de EC op 3 oktober 2017 een aanbeveling aan de lidstaten gedaan tot aanpassing van de Schengengrenscode. ${ }^{24}$ De voorgestelde wijziging ziet op het aanpassen van de regels rondom het tijdelijk herinvoeren van binnengrenscontroles in het geval van aanhoudende en ernstige bedreigingen van de openbare orde of interne veiligheid (artikelen 25 en 27 van de Schengengrenscode). Het voorstel heeft als doel te voorzien in maatregelen voor lidstaten in situaties wanneer zich in het Schengengebied een ernstige bedreiging van de openbare orde of binnenlandse veiligheid voordoet. De voornaamste voorgestelde wijziging ziet op een verruiming van de termijnen voor het uitvoeren van de binnengrenscontroles in de Schengenlanden. Onder strikte voorwaarden wordt de maximale duur voor deze maatregel verruimd van zes maanden tot één jaar. In uitzonderlijke situaties is het mogelijk deze periode te verlengen met twee jaar. Deze bevoegdheid is gekoppeld aan procedurevereisten waaraan de lidstaten moeten voldoen voordat zij de binnengrenscontrole mogen herinvoeren of verlengen. De legitimatie van de verlenging van de termijn wordt onder meer gevonden in omvangrijke secundaire migratie en de dreiging van terrorisme. ${ }^{25}$ De aanslagen in Parijs (2015) en Brussel (2016) waren ook voor Nederland aanleiding om het MTV te intensiveren. Het kabinet-Rutte III kan instemmen met de voorgestelde aanpassing, maar meent dat lidstaten niet beknot mogen worden in hun bevoegdheden en verantwoordelijkheid inzake de bescherming van de nationale veiligheid. ${ }^{26}$ Nationale veiligheid behoort tot de competentie van de lidstaten, menen de noordwestelijke lidstaten, terwijl de zuidoostelijke lidstaten voorstander zijn van een zware consultatieprocedure. Het is natuurlijk de vraag of de grote terughoudendheid waarmee deze bevoegdheden in de aanbeveling worden toegestaan, uiteindelijk ertoe zal leiden dat het vrij verkeer in het Schengengebied wordt uitgehold. Daarbij moet worden gewaakt dat de vrees voor terrorisme niet tot gevolg zal hebben dat de heringevoerde controles vooral personen zullen betreffen die passen in een radicaalislamitisch profiel dat mede is gebaseerd op etnische of religieuze kenmerken. ${ }^{27}$ Vreemdelingenrecht 2017, nr. 2, p. 23.

23 Ibidem, p. 26.

24 Aanbeveling (EU) 20127/1804 van de Commissie.

25 Ibidem, preambule nr. 4.

26 Kamerstukken II 2017/18, 22 112, nr. 2423.

27 P.R. Rodrigues en M.A.H. van der Woude, 'Proactieve politiecontrole en onderscheid naar etniciteit of nationaliteit', NJB 2016, afl. 32, p. 2294-2302. 


\section{Profileren, veiligheid en non-discriminatie}

Omdat de politie- en immigratiecontroles, uit te voeren in de intra-Schengengrensgebieden, doorgaans niet gebaseerd zijn op een concrete verdenking maar van preventieve of zelfs van proactieve aard zijn, genieten de ambtenaren betrokken bij de uitvoering van deze controles een grote mate van discretionaire beslisruimte. ${ }^{28}$ Het hebben van een dergelijke beslisruimte is, anders dan wat soms wordt beweerd, op zichzelf niet onbegrijpelijk of verwerpelijk. Juist om maatwerk te kunnen leven aan de veelheid en diversiteit van situaties die zich 'op straat' kunnen voordoen, is het noodzakelijk dat ambtenaren een zekere mate van vrijheid hebben in het beslissen of, en zo ja, hoe, ze bepaalde bevoegdheden toepassen. Discretionaire ruimte kan, met andere woorden, een belangrijke bijdrage leveren aan het nemen van rechtvaardige beslissingen. ${ }^{29}$ Het omgekeerde is echter ook het geval: discretionaire ruimte biedt ook de mogelijkheid tot misbruik. Daarbij geldt over het algemeen dat hoe onduidelijker de officiële beleidsdoelen zijn, hoe meer ruimte er ontstaat voor ambtenaren om naar eigen inzicht beslissingen te nemen. Zo vond Bastien in een studie naar het Spaanse immigratiebeleid dat ambigue doelstellingen leidden tot meer discretie onder de ambtenaren die dit beleid moesten implementeren. ${ }^{30}$

Alvorens nader stil te staan bij een van de meest in het oog springende vormen van mogelijk misbruik, etnisch profileren, is het van belang om het toenemende gebruik van preventieve en proactieve bevoegdheden en de verschillende 'instrumenten' die ter ondersteuning bij de toepassing van die bevoegdheden worden ingezet, te plaatsen binnen de bredere ontwikkeling van risicojustitie. ${ }^{31}$ Met deze laatste term wordt gedoeld op de ontwikkeling van veiligheidsbeleid dat steeds meer in het teken staat van het wapenen tegen mogelijke bedreigingen en risico's. Door middel van allerhande nieuwe straf- en bestuursrechtelijke controlebe-

28 M.A.H. van der Woude, T.J.M. Dekkers \& J. Brouwer, 'Over crimmigratie en discretionair beslissen binnen het Mobiel Toezicht Veiligheid ... of Vreemdelingen ... of Veiligheid?' Tijdschrift voor Veiligheid 2015, 14(2), 19-35; A. Pratt, 'Between a hunch and a hard place: making suspicion reasonable at the Canadian border', Social \& Legal Studies 2010, 19(4), 461-480; S. Casella Colombeau, 'Policing the internal Schengen borders - managing the double bind between free movement and migration control', Policing and Society 2017, 14(1), 63-77.

29 K. Hawkins, 'The Use of Legal Discretion: Perspectives from Law and Social Science', in: K. Hawkins (ed.), The Uses of Discretion, Oxford: Clarendon Press 1992; M.A.H. van der Woude, Chain reactions in criminal justice: discretion and the necessity of interdisciplinary research, Den Haag: Eleven International Publishers 2016.

30 J. Bastien, 'Goal ambiguity and informal discretion in the implementation of public policies: the case of Spanish immigration policy', International Review of Administrative Sciences 2009, 75(4), 665-685.

31 L.M. Moerings, Straffen met het oog op veiligheid; een onderneming voor risico's, Leiden: Universiteit Leiden 2003; M. Feeley and J. Simon, 'Actuarial Justice: The Emerging New Criminal Law', in: D. Nelken (ed.), The Futures of Criminology, p. 173-201, London: Sage 1994; H. Boutellier, 'Uitdijend strafrecht', in: J.H. Crijns, P.P.J. van der Meij \& G.K. Schoep (red.), Taak van de strafrechtswetenschap, Den Haag: Boom Juridische uitgevers 2005, p. 109-118; J. McCulloch and S. Pickering, 'Pre-crime and counter-terrorism. Imagining future crime in the war on terror', British Journal of Criminology 2009, 49, p. 628-645. 
voegdheden wordt gepoogd het net van sociale controle zo ver mogelijk te doen reiken. Passend bij de inzet van dergelijke proactieve en preventieve bevoegdheden is het gebruik van risico-inschattingen en risicoanalyses op basis waarvan wordt getracht te komen tot een profilering van personen en situaties die de (nationale) veiligheid mogelijk kunnen bedreigen. Het optreden van politie en justitie wordt niet langer geleid door concrete, individualiseerbare verdenkingen van een strafbaar feit maar door generalisaties, dat wil zeggen op basis van risicoprofielen en risico-inschatting van vooraf aangewezen 'potentieel verdachte' groepen en personen. Zedner spreekt over de verschuiving naar een pre-crime-samenleving waarbinnen het voorkomen van toekomstige schade of problemen en het inperken van allerhande maatschappelijke risico's centraal staat. ${ }^{32}$ Waar deze ontwikkeling van risicojustitie dikwijls wordt gekoppeld aan een sterkere focus op het identificeren en classificeren van potentiële criminelen, hebben verschillende auteurs gewezen op de gelijktijdige ontwikkeling van governing through migration control. ${ }^{33}$ Internationale migratie wordt in toenemende mate gezien als een problematische maatschappelijke ontwikkeling waarbij migratie en criminaliteit als onlosmakelijk met elkaar verbonden maatschappelijke problemen worden gezien, waarbij migranten, net als criminelen, worden geacht een bedreiging te vormen voor de openbare orde en (nationale) veiligheid. Volgens Bosworth en Guild heeft dit niet alleen geleid tot een meer punitieve houding ten aanzien van migratiecriminaliteit, maar ook tot het gericht inzetten van verschillende vormen van beleid om (ongewenste) buitenstaanders uit te sluiten. ${ }^{34}$ De Duitse socioloog Beck schreef in 2002 al hoe 'natuurlijk' de angst voor het onbekende en de drang naar veiligheid samen lijken te gaan met het zoeken van duidelijk zichtbare zondebokken. Zo schrijft hij: 'Is it not spies, communists, Jews, Turks or asylum seekers from the Third World who are ultimately behind it? The very intangibility of the threat and people's helplessness as it grows promote radical and fanatical reactions and political tendencies that make social stereotypes and the groups afflicted by them into 'lightning rods' for the invisible threats that are inaccessible to direct action. 35

Dit zoeken naar zondebokken zou, vertaald naar het invulling geven aan discretionaire controles, kunnen leiden tot het profileren op basis van ras, etniciteit, nationaliteit en huidskleur, hetgeen op gespannen voet staat met beperkingen die voortvloeien uit het non-discriminatie- en het gelijkheidsbeginsel zoals vastgelegd in internationaal, Europees en nationaal recht. Wanneer we kijken naar het MTV en in het bijzonder naar wat daarover in de Vreemdelingenwet 2000 en het Vreemdelingenbesluit 2000 is vastgelegd, dan valt inderdaad op dat er geen concrete richtlijnen of ijkpunten voor de selectie van personen of voertuigen zijn opgenomen anders dan dat het MTV '(...) wordt uitgevoerd op basis van informatie of ervaringsgegevens over illegaal verblijf na grensoverschrijding' (artikel

35 U. Beck, The risk society; towards a new modernity, London: Sage 1992, pp. 75-76. 
4.17a lid 2 Vreemdelingenbesluit 2000). Uitgebreid onderzoek naar het MTV heeft uitgewezen dat de discretionaire selectiebeslissing inderdaad in belangrijke mate lijkt te zijn gebaseerd op de hiervoor genoemde problematische beschermingsgronden. Hierbij spelen stereotyperingen over hoe bepaalde nationaliteiten en etnische groeperingen betrokken zouden zijn bij verschillende vormen van illegaal gedrag een belangrijke rol. ${ }^{36}$ Hoewel grootschalig onderzoek naar de wijze waarop in andere landen het intra-Schengengrenstoezicht wordt uitgevoerd in de praktijk ontbreekt, ligt het gezien de lange traditie van onderzoek naar discretionair optreden in de reguliere politiepraktijk in de lijn der verwachting dat in andere Schengenlanden vergelijkbare praktijken plaatsvinden. Een indicatie hiervoor is te vinden in het herhalingsonderzoek naar ervaren discriminatie van burgers in de Unie, uitgevoerd door het Bureau van de Europese Unie voor de grondrechten (FRA). ${ }^{37}$ Van de etnische minderheden die het afgelopen jaar door de politie waren staande gehouden, meende $40 \%$ dat het met hun herkomst van doen had. Dat betrof vooral mensen uit Azië, Noord-Afrika, Sub-Sahara en Roma. Het is de vraag in hoeverre de EC zich hiervan voldoende rekenschap heeft gegeven bij het doen van haar aanbeveling inzake evenredige politiecontroles en politiële samenwerking in het Schengengebied. ${ }^{38}$

\section{Wederzijds vertrouwen of eigen grenzen eerst}

Wanneer we kijken naar de situatie zoals die zich in de EU ontvouwt rondom het thema immigratie, dan ontstaat het beeld van een lappendeken: uit wantrouwen richting de EU en de lidstaten die verantwoordelijk zijn voor de Europese buitengrenzen lijken de verschillende lidstaten met name bezig te zijn met het waarborgen van de eigen nationale veiligheid en identiteit door het op enigerlei wijze opeisen, of wellicht beter gezegd terugeisen, van de soevereiniteit over de eigen intra-Schengengrenzen. Zo schreef Traynor in 2015 al: "There is no "European" immigration policy or regime. There is a mish-mash of national policies, a patchwork of systems and criteria which are contradictory, incoherent [and] fragmented.'39

Deze situatie is anno 2018 niet veranderd en zal ook door de aanbeveling van de EC niet veranderen, aangezien artikel 23 Schengengrenscode veel ruimte laat aan de lidstaten voor wat betreft de concrete invulling van het MTV en er, zoals hier-

J. Brouwer, M. van der Woude \& J. van der Leun, '(Cr)immigrant framing in border areas: decision-making processes of Dutch border police officers', Policing and Society 2017; Online first 14 February 2017, https://doi.org/10.1080/10439463.2017.1288731 (voor het laatst geraadpleegd op 12 januari 2018).

37 Second European Union Minorities and Discrimination Survey (EU-MIDIS II), Wenen: FRA 2017. Overigens komt Nederland ten opzichte van de andere landen 'slecht' uit dit onderzoek naar voren.

38 Id. Voetnoot 5.

39 I. Traynor, 'Refugee crisis: east and west split as leaders resent Germany for waiving rules', The Guardian, 5 September 2015, section Migration: The Observer. Via: https://www.theguardian. com/world/2015/sep/05/migration-crisis-europe-leaders-blame-brussels-hungary-germany. 
voor reeds geobserveerd, ook nog steeds gebruik wordt gemaakt van herinvoering van grenscontroles op grond van artikel 29 Schengengrenscode. De scheidslijn tussen beide maatregelen is in de Schengengrenscode dun, of althans lijkt dun omdat er weinig tot geen duidelijke empirische informatie is over hoe de 'artikel 23'-controles door verschillende landen daadwerkelijk worden uitgevoerd. Het is met andere woorden moeilijk vast te stellen in hoeverre deze controles in de prakrijk niet worden gebruikt als een verkapte vorm van permanente grenscontroles door ze 24 uur per dag uit te voeren. Dit was in Nederland in beginsel ook het geval. Zo oordeelde de Afdeling bestuursrechtspraak (ABRvS) op 28 december 2010 dat de wijze waarop het MTV werd uitgevoerd - de controles konden toen 24/7 worden uitgevoerd in een niet nader gedefinieerd gebied rondom de intraSchengengrenzen - niet in lijn was met het Melki \& Abdeli-arrest van het Hof van Justitie van de EU zoals hiervoor reeds genoemd.

De keuze tussen beide maatregelen is dan ook geen eenvoudige en komt in de kern neer op een afweging - of in ieder geval een frictie tussen - verschillende fundamentele rechten en principes. Niet in de laatste plaats een van de kernprincipes van de EU, het beginsel van vrij verkeer. Dat dit beginsel niet - letterlijk en figuurlijk - 'begrensd' zou kunnen worden, valt moeilijk te verenigen met het recht op veiligheid. Dit recht op veiligheid mag op zijn beurt echter weer niet leiden tot het stereotyperen en discrimineren van groepen en personen en mag ook zeker niet worden gezien als een recht dat automatisch ingeroepen mag en moet worden op momenten van verhoogde mobiliteit zonder dat er daarbij concrete aanwijzingen zouden zijn dat deze mobiliteit ook daadwerkelijk leidt tot risico's voor de nationale veiligheid. In dit onmogelijke spanningsveld, waarbij we de sterke politisering van zowel het thema 'veiligheid' als het thema 'migratie' niet moeten vergeten, moeten nationale overheden een beslissing nemen over 'wat te doen'. De optie om niets te doen, lijkt, juist gezien voornoemde politisering, immers niet aanwezig. Net zoals David Garland observeerde ten aanzien van politieke beslissingen op het terrein van het criminaliteitsbeleid, zien politiek leiders in de EU zich gesteld voor een bijzonder predicament, een bijzonder dilemma. ${ }^{40}$ Niets doen is geen optie, maar wel actie ondernemen is ook niet zonder problemen. Om over de te verwachten effectiviteit van deze maatregelen nog maar te zwijgen, want ook daarover ontbreken betrouwbare gegevens.

Ondanks dit gebrek aan inzicht in de praktijk van artikel 23 Schengengrenscode, hebben dergelijke controles na grensoverschrijding wat ons betreft de voorkeur boven herinvoering van (binnen)grenscontroles. Het EU-beginsel van vrij verkeer komt anders te veel op de tocht te staan. Aan de andere kant dienen de overheden van de lidstaten van de EU de veiligheid van hun burgers te beschermen. Het recht op leven (artikel 2 EVRM) is evenals het beginsel van non-discriminatie een mensenrecht. Bij de afweging van maatregelen tegen terrorisme en ter bescherming van de openbare orde dienen proportionaliteit en noodzaak voorop te staan. Op dit moment kunnen bij de proportionaliteit van grenscontroles vraagtekens

40 D. Garland, The Culture of Control. Crime and Social Order in Contemporary Society, Oxford: Oxford University Press 2001. 
worden geplaatst. ${ }^{41}$ Meer in het algemeen kunnen controlemaatregelen alleen maar effectief en uitvoerbaar zijn, indien gebruik wordt gemaakt van slimme criteria om burgers te bevragen. Uiterlijk kan daarbij volgens ons geen nuttige rol spelen, maar andere kenmerken - van het voertuig, of de samenstelling van personen in een voertuig - of bepaalde gedragingen van personen dan wel voertuigen en (combinaties van) omstandigheden wel.

Het nemen van concrete maatregelen in de EU gaat hand en hand met de discussie over de verdeling van vluchtelingen over verschillende Europese lidstaten. Dit debat verloopt niet eenvoudig en langs de eerdergenoemde scheidslijnen tussen het noordwesten en het zuidoosten. Met name economische belangen blijken hier tot een tegenstelling te leiden voor grenscontrole (noordwest) of voor open grenzen (zuidoost). Daarnaast ontstonden er fricties tussen overheden die zich aan een hoger vluchtelingenquotum hadden gecommitteerd door middel van herhuisvesting of asielverlening, overheden die slechts een beperkt aantal vluchtelingen wilden toelaten en overheden die kritisch waren op de plannen voor de distributie van vluchtelingen, gelet op de inbreuk die hiermee gemaakt zou worden op de eigen soevereiniteit en het welzijn van de 'eigen' burgers. ${ }^{42}$ De discussies over de herverdeling illustreren de groeiende spanningen tussen nationaal en supranationaal bestuur - de onvrede vanuit nationale overheden over het feit dat zij vanuit de EU opgelegd krijgen hoe zij zich moeten opstellen in reactie op de meer intensieve migratie. De EC heeft op 17 december 2017 besloten Tsjechië, Hongarije en Polen voor het Hof van Justitie van de EU te dagen wegens de niet-naleving van hun verplichtingen inzake het plaatsen van vluchtelingen (inbreukprocedure). ${ }^{43}$ Eerder hadden deze landen tevergeefs bij het Hof van Justitie van de EU gepoogd de maatregelen van tafel te krijgen. ${ }^{44}$ Zo blijkt het migratievraagstuk aan politieke en economische belangen te raken waardoor het Unierechtelijke wederzijdse vertrouwen behoorlijk op de proef wordt gesteld.

\section{Conclusies}

Het zijn, en blijven, moeilijke tijden in de Europese Unie. Ondanks het feit dat het aantal migranten is afgenomen, is de geest uit de fles voor wat betreft het migratievraagstuk. Waar er in 2015 nog 1,015,078 migranten per boot de oversteek maakten naar Europa, waren dat er 171,332 in 2017. ${ }^{45}$ Door wantrouwen in de bewaking van de externe grenzen van de Unie en twijfels over de motieven van

41 Koolstra en Slager, Ibid, p. 27.

42 R. Bauböck, 'Refugee Protection and Burden-sharing in the European Union', Journal of Common Market Studies 2017. Online first, October 2017 via: http://cadmus.eui.eu/bitstream/handle/ 1814/48844/Refugee\%20protection-11-09-2017-preprint.pdf?sequence=1\&isAllowed=y （voor het laatst geraadpleegd op 28-01-208).

43 http://europa.eu/rapid/press-release_IP-17-5002_nl.htm.

44 Het betreft het arrest van de Grote Kamer van het EU-Hof 6 september 2017, C-643/15 en 647/15 (Slowaakse Republiek en Hongarije tegen de Raad).

45 http://data2.unhcr.org/en/situations/mediterranean (voor het laatst geraadpleegd op 14/01/2018). 
migranten om naar het Europees continent te komen, zien lidstaten zich genoodzaakt om het heft in eigen handen te nemen en maatregelen in het leven te roepen die enige mate van toezicht op intra-Schengen grensmobiliteit toestaan. Dit draagt bij aan een ondoorzichtig lappendeken van maatregelen, organisaties betrokken bij of verantwoordelijk voor dit toezicht, om over de concrete uitvoering van dit toezicht maar te zwijgen. De recente poging van de EC om dit lappendeken meer te uniformeren door politiecontroles na grensoverschrijding te bepleiten, lijkt niet eenduidig aangezien tegelijkertijd tijdelijke grenscontroles door de EC worden geaccepteerd en zelfs voorstellen worden gedaan voor verdere facilitatie daarvan. Daarmee lijkt tevens de invloed van de noordwestelijke lidstaten dominant in de EC en wordt de scheurlijn met de zuidoostelijke lidstaten steeds pregnanter. De dreiging van terreur brengt mee dat de lidstaten die daardoor getroffen zijn of dreigen te worden meer autonomie opeisen ten aanzien van de bescherming van de openbare orde en bewaking van de binnenlandse veiligheid. Dat lijkt ons eerder de reden voor de maatregelen te zijn, dan de vrees voor secundaire migratie. Het lijkt ons dat hierbij het Unierechtelijke begrip van ernstige bedreiging van de openbare orde dient te worden gehanteerd en dat een nationale invulling niet volstaat. Volgens de considerans van de Schengengrenscode veronderstelt het begrip openbare orde dat er sprake is van een werkelijke, actuele en voldoende ernstige bedreiging die een fundamenteel belang van de samenleving aantast. ${ }^{46}$ In het belang van sociale cohesie in de EU dient het profiel van 'de terrorist' gevrijwaard te zijn van etnische of religieuze persoonskenmerken. 